\title{
Teacher Preparation in Ontario: A History
}

\author{
JULIAN KITCHEN \\ Brock University \\ DIANA PETRARCA \\ University of Ontario Institute of Technology
}

\begin{abstract}
As teacher education takes this dramatic term, it is useful for educators, policy-makers and the general public to situate this change in the larger history of teacher preparation in the province. This history, beginning in the $19^{\text {th }}$ century, tells the story of increasing professionalism over the years as Ontario adapted its system to meet a rising demand for elementary and secondary education. It is a story of authority over education, as teacher training under provincial direction became teacher education in universities, and as accreditation shifted to the Ontario College of Teachers. It is a story of reform, and the limits of reform, in the preparation of teachers for a diverse and changing world. By better understanding the history of teacher preparation, we may gain insight into the present situation and imagine a better future for teacher education in Ontario.
\end{abstract}

\section{Introduction}

Two years ago, the Ontario government announced that it was extending teacher education in order to "help more of our students succeed in school and take the next step in creating the world’s best-educated workforce” (Ontario Premier’s Office, 2011). Aspiring teachers will now need to complete both an undergraduate degree and a two-year teacher education program in order to be certified to teach.

As teacher education takes this dramatic term, it is useful for educators, policy-makers and the general public to situate this change in the larger history of teacher preparation in the province. This history, beginning in the $19^{\text {th }}$ century, tells the story of increasing professionalism over the years as Ontario adapted its system to meet a rising demand for elementary and secondary education. It is a story of authority over education, as teacher training under provincial direction became teacher education in universities, and as accreditation shifted to the Ontario College of Teachers. It is a story of reform, and the limits of reform, in the preparation of teachers for a diverse and changing world. By better understanding the history of teacher preparation, we may gain insight into the present situation and imagine a better future for teacher education in Ontario. 


\section{Teacher Preparation in Ontario: A History}

\section{Teacher Preparation in the Nineteenth Century}

Prior to 1847 no training or certification was required to teach in Ontario. Most teachers in the 'common' schools that served the general public were barely literate, poorly paid and itinerant. In 'grammar schools' that served the financially secure, teachers were usually clergy or university graduates with no training in pedagogy.

The Ontario Normal School was established by Superintendent of Education Egerton Ryerson in 1847 as part of the Common School Act of 1846 which included major changes to education in Ontario. Normal schools, which began in Napoleonic France, were a response to low standards in most schools, economic change, and a need for teachers for a rapidly expanding school system. The term 'normal' meant according to rule, with the focus on ensuring a focus on method rather than the needs of the children being taught.

To enrol in the Ontario Normal School in Toronto, prospective teachers had to be 16 years old, present a certificate of good moral character from clergyman, and provide evidence of skill in reading, writing and arithmetic. The first group of twenty men began their five-month program in the fall of 1847. They were followed the next April by a group of 118, including 20 women. By 1865, the program was 5 months in length for the $2^{\text {nd }}$ Class certificate and ten months for the $1^{\text {st }}$ Class certificate. In 1853 Ryerson introduced a certificate for province-wide recognition of Normal School graduates. In the early years, a high priority was placed on ensuring that teachers were familiar with subject content. As secondary education improved, Normal Schools education increasingly emphasized pedagogical training.

While training in both subject matter and pedagogy was a government priority, the standard necessary to teach at the grammar school (secondary) level was a university education. The lack of university-educated teachers presented a significant challenge in a province with a growing need for grammar school teachers. While Ryerson shared the view that a university

education was preferable, as he also valued pedagogical knowledge highly, he permitted Normal School graduates with First Class certificates to teach in grammar schools. At same time, given the need for high-level content knowledge, Ryerson authorized the formation of a model grammar school to train teachers in 1858 . The school closed in 1863 as it was not possible to staff it with appropriate instructors "versed in science and philosophy of education and experienced in the application of scientific pedagogical principles” (Fiorino, 1978, p.41). Under 


\section{Teacher Preparation in Ontario: A History}

the School Act of 1853, non-graduates had to undergo an examination based on subjects for university matriculation to be eligible. This requirement highlights the premium placed on advanced content knowledge at the time.

The School Act of 1871granted all children the right to an elementary education. Common schools became 'public' schools with mandatory attendance, which further increased the demand for teachers. The establishment of public Collegiate Institutes designed to introduce classical rigour into the high school curriculum added to the need for more teacher preparation. Evidence that normal school graduates were much more effective in the classroom than untrained teachers led to the expansion of the Ontario Normal School and the formation of another in Ottawa in 1875. In 1900, a third normal school was established in London. By 1920, there were seven normal schools in the province.

In 1885, as a means of attracting educated secondary school teachers, 54 Collegiate Institutes were designated teacher training institutions. This program was 14-weeks in duration: two weeks of general theory and organization; six of observation and tutoring by department heads in special methods and in use of texts; and six weeks in observation and practice teaching. Unfortunately, as Fiorino (1978) observes "they failed to provide the teachers-in-training any grounding in the science of education” (p. 44) and instructors provided ill-equipped to be teacher educators.

On the other hand, a teacher shortage led to the establishment of County Model Schools as a quick alternative means to certification. These model schools consisted of apprenticeships reinforced by evaluation by teachers, principals, and superindendents. These $3^{\text {rd }}$ Class certificates, which were only valid in the county, proved popular due to "their convenient locations and the shortness of their courses” (MCTST, 1966, p. 5). This resulted in, many elementary schools being primarily staffed by $3^{\text {rd }}$ Class teachers. Althouse (1929) argues that describes the effect on "the status of the profession was devastating" with teachers being "mere boys and girls" who were "scandalously over-worked” (p. 62). This $3^{\text {rd }}$ Class model did little to address problems of transience, attrition, or poor salaries.

While the government struggled to address the shortage of teachers in the late 19thcentury, it continued innovative efforts to improve the quality of teaching at the secondary level. A School of Pedagogy was established in Toronto in 1890, before being move to Hamilton in 


\section{Teacher Preparation in Ontario: A History}

1897 as the Ontario Normal College. This facility trained secondary teachers of two types: (1) high school graduates were awarded $1^{\text {st }}$ Class certificates, while (2) university graduates were awarded Ordinary or Specialist High School certificates.

A defining characteristics of Ontario teacher preparation at the time was a high degree of provincial control (LaZerte, 1950). The Department of Education had dealt with a shortage of educated and qualified teachers for its expanding public education system. It had responded to the crisis in elementary schools in two ways. Through teacher preparation in Normal Schools, teachers were provided with the necessary knowledge base and pedagogical skills for the delivery of the presecribed curriculum. On the other hand, less qualified individuals were pressed into service to meet shortages. At the secondary level, efforts were being made to attract and better prepare well educated candidates through Collegiate Institutes and, later, the specialised Ontario Normal College. In-service education, primarily during the summer, was an important means for ongoing improvement of the quality and qualifications of teachers. While universityeducated teachers were prized, teacher preparation remained entirely in the hands of the

provincial government. As the Ontario school system grew and changed in the $20^{\text {th }}$ century, universities increasingly sought a role in teacher education.

\section{Early Twentieth Century (1900-1950): Provincial Control}

At the turn of the century, Ontario education system had become large and complex. There were 8,321 elementary teachers in 5,654 public schools and 568 secondary school teachers in 130 grammar schools and collegiates.

While few people had a secondary education, population growth and the need for an educated workforce made the preparation of secondary teachers a priority. In 1906 secondary teacher educations was moved to University of Toronto as part of the first effort to engage universities in teacher preparation. As MacDonald (1996) writes:

The emerging conventional wisdom of the time... favoured the locale of formal educational studies inside the academic umbrella of the university. Initially, the feeling seemed to be that cohabitation would somehow elevate, or at least add academic legitimacy to, the fledging discipline of educational studies. (p. 4) 


\section{Teacher Preparation in Ontario: A History}

A faculty was also established at Queens University in 1907. These moves prompted a reorganization of the curriculum of the one-year program into three parts (MacDonald, 1996). First, general courses in topics such as, history and philosophy of education, psychology, school law and administration, general methods, and specialized methods in particular subjects. Second, professional and academic review of the school curricula. Third, fifty days of classroom observation and twenty school periods of practice teaching. Provision was made for Type A Specialist qualifications in subject teachables.

The move to the university, however, was fraught with difficulties that ultimately undermined this experiment. While the government valued the link between teacher education and the liberal arts university environment, subsequent administrations viewed the university program as providing poor preparation for teachers. Also, as three-quarters of students had only a secondary school education, they seemed ill-suited to the university context.

By 1920, the Queens program was discontinued. Under a new agreement between the province and the University of Toronto, the newly-named Ontario College of Education remained at the University of Toronto but was entirely controlled by the Department of Education. Enrolment was restricted to candidates possessing a university degree. Staff were appointed by the Minister and the program of study mandated by the Department.

The need for skilled labour led to efforts to promote vocational education at the secondary level. In 1925 the Ontario College for Technical Teachers began its program in Hamilton. It was a twenty-week program in autumn or spring designed to prepare vocational teachers. It could be taken in two 5-week summer sessions-or equivalent during evenings. The program began with industrial and technical subjects, with later amendments adding commercial and agricultural subjects. In 1946, the program was transferred to Toronto.

During this time, elementary education in Normal Schools continued to grow. In 1900, a third was established in London. By 1920 there were seven in the province. By the early 1920's, “Ontario's system of elementary school teacher training had achieved a marked degree of expansion, organization and consolidation” (Fiorino, p. 34). The seven normal schools graduated 1815 students in 1922-23. In addition, summer courses provided hundreds of teachers with specialized training in particular subjects. 


\section{Teacher Preparation in Ontario: A History}

Efforts to improve the qualifications and preparation of teachers, however, continued to be undermined by economic factors that led to a shortage of teachers in and after the Second World War. This challenge led to the establishment of emergency summer session leading to teaching certification from 1944 to 1953 . Students with high school diplomas could teach on a Temporary Certificate upon completion of two six-week summer courses; they could then qualify for a permanent certificate after another year of teaching. Also, diploma expectations for candidates with high school diplomas were diminished from nine Grade 13 requirements down to five.

"By 1950, Ontario had a well-structured, highly centralized, and comprehensive system of teacher education” (Fiorino, 1978, p. 74). The standard was general education through high school to become an elementary teacher and university education to teach secondary, followed by a year of professional training and professional certification after two years of successful practice. Two assumptions guided the program: (1) instruction in detailed methodology for teaching each subject, and (2) emphasis on "broad general principles of learning” (LaZerte, 1950) rather than adaptation to the needs of students or the learning contexts.

Change, however, was on the horizon as society took a greater interest in teacher education and as again became part of the teacher education conversation.

\section{0-1980: From Teachers' Colleges to Faculties of Education}

The Royal Commission on Education in Ontario (1950) consulted widely on the educational needs of the province of Ontario before presenting their report, popularly known as the Hope Report. The public consultations brought new perspectives to the forefront. According to Gidney (1999), “The recommendations of the Hope Report were broad-ranging and on some issues quite radical” (p. 23). One of the concerns of the commission was teacher preparation. In the immediate term, it recommended emergency measures to deal with the shortage of qualified teachers. It's most ambitious measure, the establishment of junior colleges of education working alongside a rejuvenated Ontario College of Education, was not implemented

In 1956, the Elementary School Teacher`s Certificate replaced $1^{\text {st }}$ Class for teachers who had completed Grade 13. The Elementary School Teacher`s Certificate was then divided into four levels in 1961. For Standard 1, a teacher needed to complete a one year program. To be promoted to Standard 2, a teacher also needed to have taken five university courses. For 


\section{Teacher Preparation in Ontario: A History}

Standard three, ten university courses. Standard 4, conferred on certified teachers who had completed a bachelor's degree, served as an incentive for elementary teachers to become highly qualified professionals.

Vocational teacher training ranged between efforts to improve credentials and efforts to alleviate shortages. A similar pattern occurred in standards for the vocational education in 1954, when the Ordinary Vocational Certificate became the Interim Vocational Certificate, with Type A designating an applied science degree plus two years experience in one's area of specialization and Type B indicating simply the completing of the certificate program with a grade of $66 \%$ or higher in all courses. By 1962, however, the re-organization of the high school program and a new vocational agreement with teachers' federations led to a vocational teacher shortage, which necessitated a five-week summer emergency program to certify less academically qualified teachers. The government also attempted to alleviate this by making provision for Ontario College of Education graduates to take commercial subjects as one of their three teaching options.

By 1965, the Teacher Education Branch of Department of Education added the training and professional development of elementary teachers its many responsibilities. While this marked the high watermark for government control, the tide was beginning to turn towards university-based teacher education.

“The teacher is the keystone of the education arch," wrote the Royal Commission (1950, p. 564) in the section on teacher education. The Report recommended coordination between universities and the Department of Education in the preparation of teachers. Support was expressed for a Bachelor's degree as the minimum standard for admission. This reflected an emerging consensus that education was necessary for all. Debate now focussed on the nature of an extended program. Should extra time be devoted to the study of content areas or on the development of professional content knowledge? The Ontario Public School Men Teachers' Federation (1951) proposed a three-year program in which the first year focussed on general knowledge, with only a tenth of the time devoted to teacher preparation, followed by increased focus on principles of education and directed teaching in the ensuing two years.

While changes to teacher preparation in the 1950's were modest, the term Teachers' College replaced Normal School in 1953. 


\section{Teacher Preparation in Ontario: A History}

Significant changes had to wait until the 1960’s, when Minister of Education William Davis embraced several measures that profoundly transformed education and teacher education in Ontario. On a conceptual level, by accepting the work of the Report of the Minister's Committee on the Training of Secondary School Teachers (1962), known as the Patten Report, the government moved away from the image of a teacher as transmitter of knowledge to one of “a participating, creative responsible person who must be skilled in the complexities and subtleties of the educational process in a democratic society” (p. 17). This report also led to the development of teacher education program at the University of Western Ontario and Queens University. The Report of the Minister's Committee on the Training of Elementary School Teachers [MCTEST] (1966), known as the McLeod Report, suggested that the one-year preservice program with supplementary in-service courses was no longer considreed satisfactory. “This central control of college has tended to produce a uniform program for all the college, a program which has become increasingly rigid as new subjects have been/ added to the school curriculum, causing the required material in methods to be very heavy for a one-year course,” stated the McLeod Report (MCTEST, 1966, pp.11-12). A reappraisal was need into order achieve the goal of a "well-articulated program of cumulative education from kindergarten through graduate school” (MCTEST, 1966, p. 15).

These reports channelled the desire for change into a series of recommendations that created the faculties of education model in Ontario today. Teacher education was to be transferred to universities, with the expectation that some universities might opt to specialize in elementary or secondary. For elementary education, the preference was a concurrent education program: an undergraduate baccalaureate combined with professional certification. For secondary, given the need for subject specialization, the preference was a consecutive program: an undergraduate degree followed by a professional certification program. For elementary teachers, the McLeod report noted, the program should be 75\% academic and 25\% professional preparation, which was easily achieved through a three-year general Bachelors degree and a oneyear Bachelor of Education. In addition to the liberal or academic studies in the university, prospective teachers would also be expected to study (1) foundations of education, such as psychology, philosophy and sociology; (2) curriculum and instruction, and (3) practice teaching. 


\section{Teacher Preparation in Ontario: A History}

Teacher educators would need to combine scholarship, professional practice and good human qualities. While a place was envisioned for scholars with doctorates, "in the areas of methodology and foundations of education nothing can replace the wisdom and insight gained through successful teaching experience within the school system.” (MCTES, 1966, p. 44). Maintaining links with classrooms and keeping up with educational trends were also deemed essential, as were sabbaticals, conference release time, and publishing in professional and academic journals. An important role was also envisaged for graduate work by educators.

The change in course signalled by the McLeod Report was locked in place by the HallDennis Report, titled Living and learning (Provincial Committee on Aims and Objectives of Education in the Schools of Ontario [PCAOESO], 1968). The report declared: "The focus is more on how to learn and think, and less on what we know and remember. Education is becoming a process, rather than a thing” (p.123).

The focus of teacher education programs, the Hall-Dennis Report concluded, needed to shift teaching to learning, with an "emphasis on child-centred programs and child development approaches” (PCAOESO, p. 130). "Improvement in the selection and education of teachers is fundamental to the improvement of education in Ontario,” the Report noted (PCAOESO, p. 129). The report emphasized the need for more teacher preparation, with a prominent role for universities in the future. While the Hall-Dennis Report acknowledged that there had been a need to hire teachers with lesser credentials - most secondary school teachers had only two summer of professional preparation-it expressed relief that this program was being terminated. The Report was critical of traditional programs as being "based on an inflexible schedule carried out in a traditional way, with limited experimentation” (PCAOESO, p. 129) under central Departmental control. Also, as the Report expressed concern that “teachers' colleges are limited in type and number in comparison with the colleges of education,” (PCAOESO, p. 130), it recommended equality of pay and facilities, as well as housing elementary and secondary teacher education in the same faculties.

While the Hall-Dennis Report weakened the grip of the Department of Education, it was leery of giving full control to universities. Its priority was ensuring the full recognition of teaching as a profession. The Report recommended, "As teacher education becomes a university program, the responsibility for certification should be shared by the university and teachers' 


\section{Teacher Preparation in Ontario: A History}

professional organizations” (PCAOESO, p. 133) through a proposed College of Teachers of Ontario.

The Ontario College of Education's lock on secondary certification was broken in the 1960’s with new Faculties of Education established at Queens and University of Western Ontario. In 1973, the Faculty of Education became part of University of Toronto again. During this period, more authority was handed to universities, with the understanding that the staff of teachers' colleges and the Ontario College of Education were to be absorbed into the universities. Most of the recommended changes to teacher education were endorsed and implemented by Minister Davis. In 1974, Regulation 269 defined teacher qualifications, prescribed curriculum, divided qualfication in Primary/Junior, Junior/Intermediate/Senior, and Technological Studies. It also defined Additional Qualifications, specialist courses, and principalship courses. While the province still controlled teacher certification, in practice it simply accepted the graduates of universities that underwent cyclical programs reviews. The decentralization of teacher education was part of a broader pattern of decentralization that saw provincial examinations eliminated and curriculum guidelines replaced tightly-prescribed provincial of courses of study.

The shortage of secondary teachers, which had led to emergency measures in the 1960's, was largely a thing of the past. In the 1970`s, teaching shifted from being a career of last resort or to a respected profession with high standards of admission and competitive salaries and benefits.

Teaching was a profession, and universities were largely in control of teacher education. The expectations for learning, teaching and teacher education rose, but there was also much criticism of programs and performance.

\section{0-Present: Teacher Education Under Fire}

By 1990, there were ten Faculties of Education in Ontario. Nipissing, Ottawa (in English and French), Toronto, Western Ontario and Windsor all offered one-year consecuative programs, while York offered only a concurrent undergraduate/preservice program. Brock, Lakehead, Laurentian (French) and Queens offered both concurrent and consecutive streams. While the move was viewed positively, universities feared that the Ministry of Education was unwilling to divest itself of responsibility for the organization and administration of programs. For the most 


\section{Teacher Preparation in Ontario: A History}

part, however, faculties of education "fundamentally changed views on teaching, from technical practice to theories related to teaching and learning” (Gannon, 2005, p. 112).

Other stakeholders, however, feared that universities "hold closely to the notion of university autonomy and, in the opinion of many observers, do only what they please," observed the Royal Commission on Learning in Ontario (1995, v. 3, p. 13). Gannon (2005) attributes this tension to the struggle for control of professionalization between faculties of education, which focus on the relationship between scientific research and practice” (p. 110) and teacher unions, which focus on teacher autonomy and working conditions. Fullan, Connelly and Watson (1989), highlighted the desire among stakeholders for an Ontario Council for Teacher Education "to increase the sense of professional control of teacher education, and to do so in a collaborative way” (p. 74).

While universities were successful in wresting control, teacher education remained fraught with controversy. Whereas teachers' colleges were viewed as too narrow and practical in focus, university-based teacher education was "largely seen as an irrelevant or hopeless player in educational reform (Sheehan \& Fullan, 1995, p. 89).” Faculties of education were viewed as “places where theory and research appear more important than practice” (Sheehan \& Fullan, 1995, p. 90). In a "climate of economic and educational decline or stagnation" (Fullan, Connelly \& Watson, 1989, p. 98), there was both pressure for further reform and reactionary pressure to turn back from recent reforms. Fullan, Connelly and Watson (1989) challenged faculties of education to accept responsibility and meet the challenge for "not only the viability of teacher education institutions but the long term health of our teachers and our schools.” (p. 100).

The persistent debate about education led to the Royal Commission on Education in Ontario (1995). The Royal Commission (1995) acknowledged “a climate of uncertainty" (vol. 1, p.1) caused by economy and technological change, limited public funds, worries about the viability of traditional social institutions, and changes to the population of Ontario. For the Love of Learning reflected their confidence "that a high-quality, effective, lifelong learning system is a realistic possibility for this province” (p.5) with teacher development (including teacher education) being one of the four engines of change. While the Royal Commission praised teacher education programs and instructors, it also recommended that teacher education be overseen by stakeholders through a newly created Ontario College of Teachers (OCT). 


\section{Teacher Preparation in Ontario: A History}

Thirty years after being recommended in the Hall-Dennis Report, the Ontario College of Teachers became the self-regulating body for the profession and a body dedicated to ensuring that the teaching profession become more accountable to the public. Among its duties was the accreditation of all teacher education programs and providers. As recommended by the Ontario College of Teachers Implementation Committee (1995) wrote, “The College must have the authority to establish standards for teacher education and the power to ensure that the standards are met” (p. 7). OCT regularly accredits teacher education programs through a very rigorous and complex process, but the focus is demonstrating evidence of compliance with the regulations for teacher education rather than guiding teacher education practice. As Gannon (2005) discovered in her interviews of deans and union leaders, government involvement in the regulation of the teaching profession has not been eliminated or even reduced by the introduction of OCT. They view the College as merely another bureaucratic structure, which provides no assurance of improved quality of teaching” (p. 130).

The decision to teacher education a two-year program serves as a reminder that authority rests with the government of Ontario. While the College has the power to review and accredit programs, it does to determine the regulations to be followed or to decree how faculties of education should organize their courses or programs. It does, however, ensure "some regularities across university-based pre-service programs” (Darling-Hammond \& Lieberman, 2012, p. 159) with the teacher induction program and ongoing professional development building effectively on it (Levin, 2012). Faculties of education, while receptive to reform, are unwilling to sacrifice the autonomy to develop their own distinct programs. As teacher education is deeply embedded within university governance structures, both the Ministry and OCT are constrained in the powers they can readily employ to reform teacher education.

These three stakeholders are intimately involved in teacher education, but interdependence is not the same as collaboration. While, as the Organisation for Economic Cooperation and Development (2011) notes, teacher development and overall educational attainment in Ontario are positive, more needs to be done to increase collaboration and ensure that teacher education continues to be responsive to educational needs in Ontario. 


\section{Teacher Preparation in Ontario: A History}

\section{In Conclusion: Themes across the History of Teacher Education in Ontario}

Knowledge of the history of teacher preparation in Ontario helps place contemporary teacher education discussions in a broader context. While each person reads history through his or her own personal and ideological lenses, there are themes that emerge across the decades. Some of these themes may merit consideration in the current debate about teacher education in Ontario.

One theme is the general educational expectations for teachers. For much of the $19^{\text {th }}$ century, the ideal elementary teacher possessed was a high school graduate and the ideal secondary school teacher was university educated. By the end of the century, an improved high school system ensured that most teachers had successfully graduated from the school system. In the 1950's and 1960's, despite teacher shortages, the earlier ideal became the norm with university education the new ideal. New teachers often lacked university degrees, but the gradations in the levels of the teaching certificate provided incentives for teachers to upgrade their general education. Since the 1980's, graduates of teacher education programs also have completed at least one other university degree and, as acceptance rates have typically been low, teacher candidates tend to have high grades in university.

A second theme is that standards of professional training have steadily risen. In 1847, Normal School became the expectation for elementary teachers. Even secondary teachers, for whom a university degree was preferred, were urged to balance academic knowledge with preparation in a Normal School. Throughout the $19^{\text {th }}$ century, efforts were made to promote education as a profession, as reflected in vocational teacher training and training in the collegiate institutes. In the $20^{\text {th }}$ century, there have been efforts to extend teacher education programs from eight months or so to as much as two-years. While these efforts have not been successful, better general education has permitted these short-duration teacher education programs to focus on the development of professional knowledge and skills.

Variations in the availability of qualified teachers is a third theme. For much of the history, there has been a significant shortage in the number of teachers. While normal schools were the $19^{\text {th }}$ century mode, far more teachers were under-qualified and prepared in County Model Schools. Similarly, major shortfalls in the 1950's and 1960's led to the emergency measures to locate teachers for a growing school system. When pay was competitive, as in the 


\section{Teacher Preparation in Ontario: A History}

1930's or today, more capable and qualified teachers are drawn into the system. Unfortunately, periods of financial generosity are soon offset by periods of fiscal caution. Major initiatives to prepare teachers fell short in the 1850's and 1870's due to the cost of educating teachers and, until recently, teacher pay has not generally been competitive.

A fourth them is that periods of progressive education, starting with the 1840's when Normal Schools were established, are generally followed by periods of caution or conservative backlash. Most notable were the reforms of the early 1900's that placed teacher education in the universities. This innovation did not last long, as a conservative public and suspicious teachers resisted this re-imagining of professional preparation. The innovative plans in the Hope Report were not implemented until the late 1960's, while the progressive language of the Hall-Dennis Report prompted a backlash in the 1990's.

Tensions between theory and practice constitute a fifth theme. While Normal Schools were valued for the knowledge they imparted, others stressed importance of field experience. Model schools, even though they prepared teachers without sufficient qualifications for Normal School, were praised by others for the practical experiences provided. Similarly, the criticism made about university-based teacher education in the early 1900's persist four decades after teacher education migrated to the university setting in the 1970's.

A sixth theme concerns the control over teacher preparation. Until the 1960's, teacher preparation was centrally controlled by the Department of Education. Even after shifting teacher education to universities, the Ministry of Education has set regulations and monitored compliance. More recently, the Ontario College of Teachers has assumed responsibility for accreditation, but the Ministry is guiding current discussions about teacher education reform. Faculties of education, while interested in consultation with stakeholders, are reluctant to give up their recently won freedom to develop their own programs.

As Ontario citizens and stakeholders critically examine the role of the education system in a period of diversity and change, teacher education will continue to be a topic of great debate. The history of teacher preparation helps us better understand these perennial issues and understanding the lessons of history can help us continually improve the preparation of teachers. 


\section{Teacher Preparation in Ontario: A History}

Dr. Julian Kitchen is an Associate Professor in the Teacher Education Department at Brock University. In addition to his research in teacher education and Aboriginal education, he has conducted numerous workshops on LGBTQ issues for Brock students.

Dr. Diana Petrarca is an Assistant Professor teaching courses in curriculum methods, assessment, webbased learning tools, and leadership in the Faculty of Education at the University of Ontario Institute of Technology. Her research centres on pre-service teacher education and how faculties of education can enhance partnerships with associate teachers, by providing them with web-based learning supports to carry out their critical role working with teacher candidates in schools.

\section{References}

Althouse , J.G. (1929/1967). The Ontario teacher: A historical account of progress, 1800-1910. Toronto, ON: Ontario Teachers Federation.

Council of Ontario Universities (1978). A report of the ad hoc working group of members of the Association of Deans of Education in Ontario Universities and members of the Council of Ontario Universities. Toronto, ON: Author.

Darling-Hammond, L. \& Lieberman, A. (2012). Teacher education around the world: What can we learn from international practice? In L. Darling-Hammond and A. Lieberman (Eds.), Teacher education around the world: Changing policies and practices (pp. 151-169). New York: Routledge.

Fiorino, A. (1978). Teacher education in Ontario: A history 1843-1976. Toronto, ON: Commission on Declining School Enrolment in Ontario.

Fullan, M.G., Connelly, F.M. \& Watson, N. (1989). Teacher education in Ontario: Options for the future. Toronto, ON: Ontario Ministry of Education.

Gannon, R.E. (2005). The role of the Ontario College of Teachers in the professionalization of teaching. Unpublished doctoral thesis, University of Toronto, Toronto, Ontario, Canada.

Gidney, R.D. (1999). From Hope to Harris: The reshaping of Ontario's schools. Toronto, ON: University of Toronto Press.

Gidney, R.D. \& Millar, W.P.J. (2012). How schools worked: Public school in English Canada, 1900-1940. Montreal, QU: McGill-Queen's University Press.

Harris, R.S. (1967). Quiet evolution: A study of the educational system in Ontario. Toronto, ON: University of Toronto Press.

LaZerte, M.E. (1950). Teacher education in Canada. Toronto, ON: W.J. Gage and Co.

Levin, B. (2012). Building capacity for sustained school improvement. In L. Darling-Hammond and A. Lieberman (Eds.), Teacher education around the world: Changing policies and practices (pp. 98-109). New York: Routledge.

MacDonald, J. (1996). A personal history of the faculty of education. In D.W. Booth and S.M. Stiegelbauer, Teaching teachers: The Faculty of Education, University of Toronto, 19061996 (pp. 2-25). Hamilton, ON: Caliburn.

Minister's Committee on the Training of Elementary School Teachers (1966). Report of the Minister's Committee on the Training of Elementary School Teachers. Toronto, ON: Ontario Department of Education. 


\section{Teacher Preparation in Ontario: A History}

Minister's Committee on the Training of Secondary School Teachers (1962). Report of the Minister's Committee on the Training of Secondary School Teachers. Toronto, ON: Ontario Department of Education.

Ontario College of Teachers Implementation Committee (1995). The privileges of professionalism. Toronto, ON: Ontario College of Teachers.

Ontario Premier's Office (August 3, 2011). McGuinty Government doubling teachers college to two years (Media Release). Canada Newswire.

Ontario Public School Men Teachers' Federation (1950). A programme for teacher education in Ontario. Toronto, ON: Author.

Organisation for Economic Co-operation and Development (2011). Lessons from PISA for the United States: Strong Performers and Successful Reformers in Education. Paris, France: OECD Publishing.

Provincial Committee on Aims and Objectives of Education in the Schools of Ontario (1968). Living and learning: The report of the Provincial Committee on Aims and Objectives of Education in the Schools of Ontario. Toronto, ON: Ontario Department of Education.

Royal Commission on Education in Ontario (1950). The Hope Commission: Report of the Royal Commission on Education in Ontario. Toronto, ON: King's Printer

Royal Commission on Education in Ontario (1995). For the love of learning: Report of the Royal Commission on Education in Ontario. Toronto, ON: King's Printer

Sheehan, N. \& Fullan, M. (1995). Teacher education in Canada: A case study of British Columbia and Ontario. In M.F. Wideen and P.P. Grimmett (Eds), Changing times in teacher education: Restructuing or reconceptualization? London: Falmer Press. 